\section{A dehydration and celloidin impregnation cycle for central nervous system material using tissue-processing apparatus (Histokinette)}

N. L. RUSSELL AND A. T. SANDISON From the University Pathology Department, Western Infirmary, Glasgow

The processing of tissue by the celloidin-embedding technique has many advantages over paraffin wax embedding, especially for material from the central nervous system. However, because of the prolonged time required for celloidin impregnation many non-specialist pathological laboratories prefer paraffin-embedding techniques.

The following modification using an automatic tissue processing machine considerably reduces the time spent on dehydration and impregnation with celloidin. The cycle is complete in 160 hours for central nervous system blocks measuring approximately $70 \times 60 \times 10 \mathrm{~mm}$. This is the block size commonly processed in routine neuropathological departments and may readily be fitted into the large stainless tissue containers used with the parallel-sided carrier (see note 2). Very satisfactory results have been obtained with complete dehydration and impregnation and no adverse effects have been found in section cutting even from blocks which have been stored in $70 \%$ methylated spirit for at least five years.

\section{Method}

The 160-hour cycle uses a seven-day clock with a seven-day card.

Received for publication 9 February 1970.
1 $70 \%$ methylated spirit .. .. 6 hours $80 \%$ methylated spirit .. $\quad . .66$ hourso

$\begin{array}{llll}\text { Methylated spirit } & \text {.. } & \text {.. } & 6 \text { hours? }\end{array}$

4 Absolute spirit 74 OP I.. . .. 12 hours

5 Absolute spirit 74 OP II. . . . 12 hours

6 Absolute spirit 74 OP III .. 12 hours

7 Absolute spirit 74 OP and ethyl ether equal parts. . .. ..

. $\quad \ldots \quad \ldots 20$ hours

$94 \%$ Celloidin $\quad . . \quad \ldots \quad$.. 20 hours

$106 \%$ Celloidin $\quad . . \quad \ldots \quad . . \quad 20$ hours?

$118 \%$ Celloidin $\quad . . \quad \ldots . \quad \ldots 20$ hours

$1210 \%$ Celloidin .. $\quad . . \quad \ldots 20$ hours

The tissue is then removed from the machine $\omega$ blocked out in $15 \%$ celloidin, allowed to harden in the usual manner, and cut on a sledge microtome.

\section{Technical Notes}

The beakers containing $8 \%$ and $10 \%$ celloidin are preferably placed on the machine platform at some convenient time before the tissue carrier descends into each of the two solutions. This reduces the evaporation which may take place from this concentration of celloidin in an openo container.

The general-purpose parallel-sided tissue carrier which holds the $2 \frac{15}{16}$ in. diameter by $\frac{7}{16}$ in deep stainless tissue cassettes is no. 78244 in the catalogue (January 1968) of Hendry $\overrightarrow{0}$ Relays Ltd.

The celloidin used is BDH 301/261.

The tissue carrier containers may be cleaned either by soaking in a dish of equal parts ether and absolute spirit until the celloidin dissolves or they may be left to dry. When dry the celloidin is readily stripped off. 